\title{
Kinetic and thermodynamic properties of soybean grains during the drying process
}

\author{
Daniel Emanuel Cabral de Oliveira, ${ }^{1}$ Osvaldo Resende, ${ }^{2}$ Jaqueline Ferreira Vieira Bessa, ${ }^{2}$ \\ Adrieli Nagila Kester ${ }^{2}$ \\ ${ }^{1}$ UFMT. Av. Alexandre Ferronato, Setor Industrial Sul Sinop; ${ }^{2}$ IF Goiano. Rodovia Sul Goiana, Rio \\ Verde, GO
}

\begin{abstract}
The aims of this work were to adjust different mathematical models to experimental data describing the drying of the Valiosa cultivar soybean grain, to determine and to evaluate the effective diffusion coefficient and to obtain the activation energy and the thermodynamic properties of the drying process under different air conditions. The experiments were conducted at the Federal Institute of Education, Science and Technology of Goiás (Instituto Federal de Educação, Ciência e Tecnologia Goiano - Câmpus Rio Verde). The Valiosa cultivar soybean grains, with an initial moisture content on a dry basis of 0.56 (d.b., decimal), were dried in an oven with forced air ventilation at five different temperatures $\left(40,55,70,85\right.$ and $\left.100^{\circ} \mathrm{C}\right)$ until reaching a moisture content of $0.133 \pm 0.019$ (d.b.). Of the models analyzed, Page's model was selected to best represent the drying phenomenon. The effective diffusion coefficient of soybeans increased with the air temperature and was described by the Arrhenius equation; an activation energy of $22.77 \mathrm{~kJ} \mathrm{~mol}^{-1}$ was reported for liquid diffusion in the drying of the soybeans. The enthalpy and entropy decreased with increasing temperature, while the Gibbs free energy increased with increasing drying temperature.
\end{abstract}

\section{Introduction}

The soybean (Glycine max) is the most commonly grown oilseed in the world because of its high protein content, which is important for the diets of humans and animals raised for human consumption

Correspondence: Osvaldo Resende, Instituto Federal Goiano, Rodovia Sul Goiana, Km 01. Zona Rural. C. Postal 66. Rio Verde, G0

E-mail: osvresende@yahoo.com.br

Key words: Glycine max, liquid diffusivity, enthalpy, entropy, Gibbs free energy.

Acknowledgements: the authors extend thanks to CNPq, CAPES and IF for their financial support for this work.

(C) Copyright D.E. Cabral de Oliveira et al., 2013

Licensee PAGEPress, Italy

Journal of Agricultural Engineering 2013; XLIV(s2):e66

doi:10.4081/jae.2013.s2.e66

This article is distributed under the terms of the Creative Commons Attribution Noncommercial License (by-nc 3.0) which permits any noncommercial use, distribution, and reproduction in any medium, provided the original author(s) and source are credited.
(Carvalho, 2012). The soybean culture is one of the most important cultures in Brazil, as it corresponds to $40 \%$ of the total grain produced in the country and $27 \%$ of the grain produced worldwide. Brazil is the second largest producer and the largest exporter of soybeans, and soybeans account for $20 \%$ of exports in Brazilian agribusiness (Vernetti and Vernetti Junior, 2009).

The purpose of drying agricultural products is to ensure their quality during storage, as the reduction in the moisture content reduces the biological activity and the chemical and the physical changes that occur during storage.

The study of drying provides information on the heat and mass transfer that occur between the biological material and the drying element (usually heated or non-heated atmospheric air), which is crucial for the design, operation and simulation of drying systems and dryers (Correa et al., 2003). The use of mathematical models to simulate the drying process in dryers that operate at high temperatures is an important tool for engineers who work in the field of drying and storage of grains (Queiroz et al., 1999).

The liquid diffusion theory has been widely used to study the drying of vegetable products. According to Corrêa et al. (2006), the liquid diffusion mechanism is complex because of the diversity in chemical compositions and physical structures of the product. Water diffusion in agricultural products involves different mechanisms, including molecular diffusion, capillary diffusion, surface diffusion, hydrodynamic flow, vapor diffusion and thermal diffusion (Goneli et al., 2009).

Knowledge of the thermodynamic properties involved in the drying of agricultural products allows engineers to design better drying equipment, to calculate energy requirements necessary for the process, to study the properties of adsorbed water, to evaluate the microstructure of food and to study the physical phenomena that occur at the material surface (Corrêa et al., 2010).

The aim of this study was to obtain the drying curves and evaluate the liquid diffusion and the thermodynamic properties of Valiosa cultivar soybean grains dried under different air- drying conditions.

\section{Materials and methods}

The experiments were conducted in the Laboratory for the Postharvest of Vegetables Products (Laboratório de Pós-colheita de Produtos Vegetais) at the Federal Institute of Education, Science and Technology of Goiás (Instituto Federal de Educação, Ciência e Tecnologia Goiano - Câmpus Rio Verde) with Valiosa cultivar soybean grains from the municipality of Santa Helena de Goiás (G0). The initial moisture content of the grains on a dry basis was 0.56 (d.b., decimal); these grains were dried in an oven with forced air ventilation at five different temperatures $\left(40,55,70,85\right.$ and $\left.100^{\circ} \mathrm{C}\right)$, leading to relative humidities of $25.3,12.5,5.7,3.5$ and $2.2 \%$, respectively. The drying con- 
tinued in an oven at $105 \pm 1^{\circ} \mathrm{C}$ for $24 \mathrm{~h}$ in three replications until the grains reached a moisture content of $0.133 \pm 0.019$ (d.b.) (Brazil, 2009).

The reduction in the moisture content during drying was monitored with the gravimetric method (mass loss) using a scale with a resolution of $0.01 \mathrm{~g}$; knowing the initial moisture content of the product, the drying continued until the desired moisture content was achieved.

The temperature and relative humidity of the external ambient environment of the drying chamber were monitored with a psychrometer, and the internal temperature was monitored with a thermometer installed inside the oven. The relative humidity of the drying air was obtained by means of the basic principles of psychrometry, using the software GRAPSI.

The moisture content ratios of the soybeans during drying were determined with the following expression:

$R X \frac{X-X_{e}}{X_{i}-X_{e}}$

where:

$\mathrm{RX}$ : ratio of the moisture content of the product, dimensionless; $\mathrm{X}$ : moisture content of the product ( $\mathrm{kg}$ of water $\mathrm{kg}^{-1}$ dry weight);

$\mathrm{X}_{\mathrm{i}}$ : initial moisture content of the ( $\mathrm{kg}_{\mathrm{g}}$ of water $\mathrm{kg}^{-1} \mathrm{dry}$ weight); and $\mathrm{X}_{\mathrm{e}}$ : equilibrium moisture content of the product ( $\mathrm{kg}$ of water $\mathrm{kg}^{-1}$ dry weight).

The equilibrium moisture content of the soybeans at each temperature was obtained

with the modified version of Henderson's equation, as reported by Asae (1988).

The experimental data describing the drying process of the soybeans were adjusted with mathematical models commonly used to represent the drying of agricultural products; these models are presented in Table 1.

The mathematical models were fitted using nonlinear regression with the Gauss- Newton method using statistical software. The models were selected according to the determination coefficient $\left(\mathrm{R}^{2}\right)$, the chisquare test $\left(\chi^{2}\right)$, the relative average error $(\mathrm{P})$ and the standard deviation of the estimate (SE). A relative average error of less than $10 \%$ was considered a criterion for model selection, as recommended by Mohapatra and Rao (2005).

$\mathrm{P}=\frac{100}{\mathrm{~N}} \sum \frac{|\mathrm{Y}-\hat{\mathrm{Y}}|}{\mathrm{Y}}$

$$
\begin{aligned}
& \mathrm{SE}=\sqrt{\frac{\sum(\mathrm{Y}-\hat{\mathrm{Y}})^{2}}{\mathrm{GLR}}} \\
& \chi^{2}=\frac{\sum(\mathrm{Y}-\hat{\mathrm{Y}})^{2}}{\mathrm{GLR}}
\end{aligned}
$$

where:

Y: experimental value;

$\hat{Y}$ : value calculated by the model;

$\mathrm{N}$ : number of experimental observations;

GLR: degrees of freedom of the model (number of experimental observations minus the number of model coefficients).

The liquid diffusion model for the spherical geometric form with the approximation of eight terms (Equation 2) was fitted to the experimental data describing soybean drying according to the expression:

$$
\mathrm{RX}=\frac{\mathrm{X}-\mathrm{X}_{\mathrm{e}}}{\mathrm{X}_{\mathrm{i}}-\mathrm{X}_{\mathrm{e}}}=\frac{6}{\pi^{2}} \sum_{\mathrm{n}=1}^{\infty} \frac{1}{\mathrm{n}^{2}} \exp \left[-\frac{\mathrm{n}^{2} \cdot \pi^{2} \cdot \mathrm{D} \cdot \mathrm{t}}{\mathrm{R}_{\mathrm{e}}^{2}}\right]
$$

where:

RX: ratio of the moisture content of the product, dimensionless;

t: time, $s$;

$\mathrm{n}$ : number of terms;

D: liquid diffusion coefficient, $\mathrm{m} 2 . \mathrm{s}^{-1}$; and

$\mathrm{R}_{\mathrm{e}}$ : equivalent radius, $\mathrm{m}\left(2.95 \times 10^{-3} \mathrm{~m}\right)$

The volume of each grain $\left(\mathrm{V}_{\mathrm{g}}\right)$ was obtained by measuring the three orthogonal axes (length, width and thickness) of fifteen grains at the end of drying with a digital caliper with a resolution of $0.01 \mathrm{~mm}$, according to the expression proposed by Mohsenin (1986):

$\mathrm{V}_{\mathrm{g}}=\frac{\pi \cdot \mathrm{A} \cdot \mathrm{B} \cdot \mathrm{C}}{6}$

were:

$\mathrm{V}_{\mathrm{g}}$ : grains volume, $\mathrm{mm}-3$; A: length, $\mathrm{mm}$;

B: width, mm; and

C: thickness, mm.

The relationship between the effective diffusion coefficient and the increase in drying air temperature was described with the Arrhenius

\begin{tabular}{|c|c|c|}
\hline Model equation & Model & \\
\hline $\mathrm{RX}=1+\mathrm{at}+\mathrm{b} \mathrm{t} 2$ & Wang and Sing & (2) \\
\hline $\mathrm{RX}=\exp \left(-\mathrm{k} \cdot \mathrm{t}^{\mathrm{n}}\right)$ & Page & (3) \\
\hline$R X=\exp (-k \cdot t)$ & Newton & (4) \\
\hline$R X=a \cdot \exp (-k \cdot t)+c$ & Logarithmic & (5) \\
\hline $\mathrm{RX}=\mathrm{a} \cdot \exp (-\mathrm{k} \cdot \mathrm{t})$ & Henderson and Pabis & (6) \\
\hline $\mathrm{RX}=\mathrm{a} \cdot \exp \left(-\mathrm{k} \cdot \mathrm{t}^{\mathrm{n}}\right)+\mathrm{b} \cdot \mathrm{t}$ & Midilli & (7) \\
\hline$R X=a \cdot \exp (-k \cdot t)+(1-a) \exp (-k \cdot a \cdot t)$ & Two exponential terms & (8) \\
\hline $\mathrm{RX}=\mathrm{a} \cdot \exp \left(-\mathrm{k}_{0} \cdot \mathrm{t}\right)+\left(\mathrm{b} \cdot \exp \left(-\mathrm{k}_{1} \cdot \mathrm{t}\right)\right.$ & Two terms & (9) \\
\hline$R X=a \cdot \exp (-k \cdot t)+(1-a) \cdot \exp (-k \cdot b \cdot t)$ & Diffusion approximation & $(10)$ \\
\hline$R X=a \cdot \exp (-k \cdot t)+(1-a) \exp \left(-k_{1} \cdot t\right)$ & Verma & (11) \\
\hline$R X=\exp \left(\left(-a\left(-a^{2}+4 \cdot b \cdot t\right)^{0,5} / 2 \cdot b\right.\right.$ & Thompson & $(12)$ \\
\hline
\end{tabular}
equation.

Table 1. Mathematical models used to predict the drying of agricultural products.

where: $\mathrm{t}$ : drying time, $\mathrm{h} ; \mathrm{k}, \mathrm{k}_{0}, \mathrm{k}_{\mathrm{l}}$ : drying constants $\mathrm{h}^{-1} ;$ and $\mathrm{a}, \mathrm{b}, \mathrm{c}$, n: models coefficients. 
$\mathrm{D}=\mathrm{D}_{\mathrm{O}} \cdot \exp \left(\frac{-\mathrm{E}_{\mathrm{a}}}{\mathrm{R} \cdot \mathrm{T}_{\mathrm{ab}}}\right)$

where:

$\mathrm{D}_{0}$ : pre-exponential factor;

$\mathrm{E}_{\mathrm{a}}$ : activation energy, kJ.mol-1;

R: universal gas constant, 8.134 kJ.kmo- ${ }^{1} 1 . \mathrm{K}^{-1}$; and

$\mathrm{T}_{\mathrm{ab}}$ : absolute temperature, $\mathrm{K}$.

The thermodynamic properties of the drying of soybean grains were obtained with the method reported by Jideani and Mpotokwana (2009):

$\Delta \mathrm{H}=\mathrm{E}_{\mathrm{a}}-\mathrm{R} \cdot \mathrm{T}$

$\Delta \mathrm{S}=\mathrm{R} \cdot\left(\ln \mathrm{k}-\ln \frac{\mathrm{k}_{\mathrm{B}}}{\mathrm{h}_{\mathrm{p}}}\right)-\ln \mathrm{T}_{\mathrm{abs}}$

$\Delta \mathrm{G}=\Delta \mathrm{H}-\mathrm{T}_{\mathrm{abs}} \cdot \Delta \mathrm{S}$

where:

$\Delta \mathrm{H}$ : enthalpy, $\mathrm{J} \mathrm{mol}^{-1}$;

$\Delta \mathrm{S}$ : entropy, $\mathrm{J} \mathrm{mol}^{-1}$;

$\Delta \mathrm{G}$ : Gibbs free energy, $\mathrm{J} \mathrm{mol}^{-1}$;

$\mathrm{k}_{\mathrm{B}}$ : Boltzmann constant, $1.38 \times 10^{-23} \mathrm{~J} \mathrm{~K}^{-1}$; and

$\mathrm{h}_{\mathrm{p}}$ : Planck constant, $6.626 \times 10^{-34} \mathrm{~J} \mathrm{~s}^{-1}$.

\section{Results and discussion}

The average values of the moisture content ratio of the soybean grains dried under different air conditions are shown in Table 2. The times required for the grains to reach the moisture content of $0.133 \pm 0.019$ ( $\mathrm{kg}$ water $\mathrm{kg}^{-1}$ dry weight) were $18.6,11.6,7.7,5.9$ and 4.7 $\mathrm{h}$ for the drying temperatures $40,55,70,85$ and $100^{\circ} \mathrm{C}$, respectively.

The increase in air temperature was found to cause a reduction in the grain drying time. The reduction in drying time is related to the greater difference between the partial pressure of water vapor in the drying air and in the product caused by the increase in temperature. This greater difference promotes an easier and more rapid water removal; similar observations were made by other authors for numerous products (Resende et al., 2008; Almeida et al., 2009; Sousa et al., 2011; Costa et al., 2011; Oliveira et al., 2012).

The values of the determination coefficient $\left(\mathrm{R}^{2}\right)$ and the relative average error $(\mathrm{P})$ of the eleven models adjusted during the drying of the soybeans at different temperatures are shown in Table 3 . The determination coefficient $\left(\mathrm{R}^{2}\right)$ was above $99 \%$ for all models and all drying temperatures, indicating, according to Madamba et al. (1996), a satisfactory representation of the phenomenon under study.

Table 2. Moisture content ratio (RX, decimal) of Valiosa cultivar soybean grains during drying time (h) under five temperature conditions $\left({ }^{\circ} \mathrm{C}\right)$.

\begin{tabular}{|c|c|c|c|c|c|c|c|c|c|}
\hline \multicolumn{2}{|c|}{$40^{\circ} \mathrm{C}$} & \multicolumn{2}{|c|}{$55^{\circ} \mathrm{C}$} & \multicolumn{2}{|c|}{$70^{\circ} \mathrm{C}$} & \multicolumn{2}{|c|}{$85^{\circ} \mathrm{C}$} & \multicolumn{2}{|c|}{$100^{\circ} \mathrm{C}$} \\
\hline Time & RX & Time & RX & Time & RX & Time & $\mathrm{RX}$ & Time & RX \\
\hline 0.00 & 1.00 & 0.00 & 1.00 & 0.00 & 1.00 & 0.00 & 1.00 & 0.00 & 1.00 \\
\hline 0.67 & 0.97 & 0.42 & 0.96 & 0.25 & 0.97 & 0.22 & 0.97 & 0.18 & 0.97 \\
\hline 1.30 & 0.92 & 0.78 & 0.92 & 0.60 & 0.92 & 0.48 & 0.92 & 0.40 & 0.90 \\
\hline 2.00 & 0.86 & 1.13 & 0.88 & 0.93 & 0.87 & 0.65 & 0.88 & 0.60 & 0.85 \\
\hline 2.40 & 0.84 & 1.52 & 0.84 & 1.20 & 0.83 & 0.85 & 0.84 & 0.77 & 0.81 \\
\hline 3.02 & 0.79 & 1.83 & 0.81 & 1.45 & 0.79 & 1.08 & 0.80 & 0.93 & 0.77 \\
\hline 3.58 & 0.76 & 2.22 & 0.77 & 1.68 & 0.76 & 1.37 & 0.75 & 1.10 & 0.72 \\
\hline 4.37 & 0.71 & 2.60 & 0.74 & 1.92 & 0.73 & 1.60 & 0.72 & 1.25 & 0.69 \\
\hline 4.85 & 0.68 & 2.98 & 0.70 & 2.17 & 0.70 & 1.80 & 0.68 & 1.42 & 0.66 \\
\hline 5.45 & 0.65 & 3.37 & 0.67 & 2.48 & 0.66 & 2.02 & 0.65 & 1.63 & 0.62 \\
\hline 6.43 & 0.61 & 3.83 & 0.64 & 2.78 & 0.63 & 2.25 & 0.61 & 1.85 & 0.58 \\
\hline 7.05 & 0.58 & 4.32 & 0.60 & 3.17 & 0.59 & 2.48 & 0.58 & 2.05 & 0.55 \\
\hline 7.72 & 0.55 & 4.78 & 0.57 & 3.52 & 0.55 & 2.70 & 0.55 & 2.23 & 0.51 \\
\hline 8.55 & 0.52 & 5.25 & 0.54 & 3.87 & 0.52 & 2.97 & 0.51 & 2.43 & 0.47 \\
\hline 9.58 & 0.48 & 5.82 & 0.50 & 4.25 & 0.48 & 3.20 & 0.48 & 2.65 & 0.44 \\
\hline 10.50 & 0.45 & 6.27 & 0.48 & 4.63 & 0.45 & 3.55 & 0.44 & 2.90 & 0.41 \\
\hline 11.53 & 0.42 & 6.80 & 0.45 & 4.97 & 0.42 & 3.85 & 0.41 & 3.13 & 0.38 \\
\hline 12.62 & 0.38 & 7.50 & 0.42 & 5.33 & 0.39 & 4.08 & 0.39 & 3.35 & 0.35 \\
\hline 13.55 & 0.35 & 8.05 & 0.39 & 5.65 & 0.36 & 4.32 & 0.36 & 3.55 & 0.32 \\
\hline 14.60 & 0.32 & 8.70 & 0.36 & 6.10 & 0.33 & 4.60 & 0.33 & 3.77 & 0.30 \\
\hline 15.68 & 0.29 & 9.45 & 0.33 & 6.62 & 0.30 & 4.88 & 0.30 & 3.97 & 0.27 \\
\hline 16.55 & 0.26 & 10.00 & 0.31 & 6.95 & 0.28 & 5.25 & 0.28 & 4.17 & 0.25 \\
\hline 17.38 & 0.24 & 10.85 & 0.28 & 7.30 & 0.26 & 5.58 & 0.25 & 4.38 & 0.23 \\
\hline 18.58 & 0.21 & 11.57 & 0.25 & 7.67 & 0.24 & 5.87 & 0.23 & 4.75 & 0.21 \\
\hline
\end{tabular}


The models presented relative average error values (P) less than $10 \%$ for the five conditions analyzed, indicating, according to Mohapatra and Rao (2005), that they provide suitable representations of the drying phenomenon. However, the Wang and Sing (2), Newton (4), Exponential of Two Terms (8) and Thompson (12) models had the highest values of $\mathrm{P}$.

The chi-square $\left(\chi^{2}\right)$ values and the estimated average error (SE) obtained for the different models adjusted to the different conditions used to dry the soybean grains are described in Table 4.

The eleven models analyzed showed low values of estimated average errors (SE), which suggests good adjustments of the models to the experimental data. All models showed significant chi-squared values. Günhan et al. (2005) reported that the lower the value of chi- square, the better the fit of the model. The Page (3), Logarithmic (5) and Midilli (7) models had the lowest chi-square values.

The analyzed models satisfactorily represented the process of soybean grain drying; however, the Page (3), Logarithmic (5) and Midilli (7) models had the best overall fits. Thus, due to its simplicity, the Page model was selected to represent the phenomenon of soybean grain drying.

Figure 1 shows the drying curves for soybean at the different studied

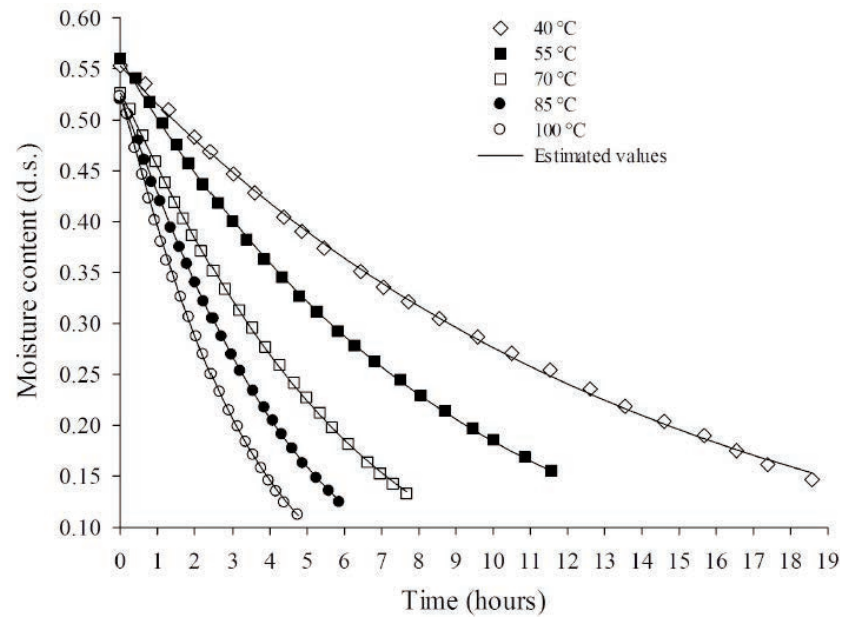

Figure 1. Drying curves, experimental data and values estimated by Page model for the soybean grains at temperatures of $40,55,70,85$ and $100^{\circ} \mathrm{C}$.

Table 3. Determination coefficient $\left(R^{2}, \%\right)$ and relative average error $(P, \%)$ for the models analyzed during the drying of soybean grains under various temperature conditions $\left({ }^{\circ} \mathrm{C}\right)$.

\begin{tabular}{|c|c|c|c|c|c|c|c|c|c|c|}
\hline \multirow{3}{*}{ Models } & \multicolumn{10}{|c|}{ Temperature $\left({ }^{\circ} \mathrm{C}\right)$} \\
\hline & \multicolumn{2}{|c|}{40} & \multicolumn{2}{|c|}{55} & \multicolumn{2}{|c|}{70} & \multicolumn{2}{|c|}{85} & \multicolumn{2}{|c|}{100} \\
\hline & $\mathbf{R}^{2}$ & P & $\mathbf{R}^{2}$ & P & $\mathbf{R}^{2}$ & P & $\mathbf{R}^{2}$ & $\mathbf{P}$ & $\mathbf{R}^{2}$ & $\mathbf{P}$ \\
\hline 2 & 99.75 & 2.41 & 99.92 & 1.18 & 99.97 & 0.55 & 99.97 & 0.46 & 99.96 & 0.68 \\
\hline 3 & 99.88 & 1.69 & 99.98 & 0.43 & 99.98 & 0.68 & 99.99 & 0.48 & 99.96 & 0.83 \\
\hline 4 & 99.84 & 1.78 & 99.96 & 0.49 & 99.62 & 0.68 & 99.39 & 3.47 & 99.58 & 3.27 \\
\hline 5 & 99.91 & 1.48 & 99.98 & 0.39 & 99.98 & 0.38 & 99.97 & 0.61 & 99.97 & 0.74 \\
\hline 6 & 99.88 & 1.70 & 99.98 & 0.39 & 99.82 & 1.89 & 99.72 & 2.21 & 99.78 & 2.11 \\
\hline 7 & 99.93 & 1.19 & 99.98 & 0.41 & 99.99 & 0.39 & 99.99 & 0.31 & 99.97 & 0.68 \\
\hline 8 & 99.84 & 1.78 & 99.96 & 0.49 & 99.62 & 2.80 & 99.98 & 0.39 & 99.58 & 3.27 \\
\hline 9 & 99.89 & 1.64 & 99.98 & 0.39 & 99.82 & 1.89 & 99.72 & 2.21 & 99.97 & 0.71 \\
\hline 10 & 99.89 & 1.63 & 99.96 & 0.49 & 99.97 & 0.46 & 99.94 & 0.90 & 99.96 & 0.71 \\
\hline 11 & 99.89 & 1.67 & 99.97 & 0.41 & 99.97 & 0.46 & 99.94 & 0.90 & 99.95 & 0.80 \\
\hline 12 & 99.84 & 1.78 & 99.96 & 0.49 & 99.62 & 2.80 & 99.39 & 3.47 & 99.58 & 3.27 \\
\hline
\end{tabular}

temperatures generated from the experimental data and the values

Table 4. Values of the chi-square test (2, decimal x10-3) and estimated average error (decimal, SE) obtained for ten models used for the representation of kinetics of drying of Valiosa cultivar soybean grains.

\begin{tabular}{|c|c|c|c|c|c|c|c|c|c|c|}
\hline \multirow{3}{*}{ Models } & \multicolumn{10}{|c|}{ Temperature $\left({ }^{\circ} \mathrm{C}\right)$} \\
\hline & \multicolumn{2}{|c|}{40} & \multicolumn{2}{|c|}{55} & \multicolumn{2}{|c|}{70} & \multicolumn{2}{|c|}{85} & \multicolumn{2}{|c|}{100} \\
\hline & 2 & SE & 2 & SE & 2 & SE & 2 & SE & 2 & SE \\
\hline 2 & 0.152 & 0.012 & 0.046 & 0.007 & 0.015 & 0.004 & 0.020 & 0.005 & 0.027 & 0.005 \\
\hline 3 & 0.071 & 0.008 & 0.013 & 0.004 & 0.014 & 0.004 & 0.009 & 0.003 & 0.026 & 0.005 \\
\hline 4 & 0.095 & 0.010 & 0.020 & 0.004 & 0.013 & 0.004 & 0.352 & 0.019 & 0.254 & 0.016 \\
\hline 5 & 0.060 & 0.008 & 0.010 & 0.003 & 0.010 & 0.003 & 0.020 & 0.004 & 0.023 & 0.005 \\
\hline 6 & 0.077 & 0.009 & 0.009 & 0.003 & 0.108 & 0.010 & 0.170 & 0.013 & 0.129 & 0.011 \\
\hline 7 & 0.049 & 0.007 & 0.010 & 0.003 & 0.007 & 0.003 & 0.006 & 0.003 & 0.020 & 0.004 \\
\hline 8 & 0.099 & 0.010 & 0.021 & 0.005 & 0.227 & 0.015 & 0.010 & 0.003 & 0.266 & 0.016 \\
\hline 9 & 0.073 & 0.009 & 0.010 & 0.003 & 0.119 & 0.011 & 0.187 & 0.014 & 0.023 & 0.005 \\
\hline 10 & 0.072 & 0.008 & 0.022 & 0.005 & 0.018 & 0.004 & 0.040 & 0.006 & 0.026 & 0.005 \\
\hline 11 & 0.074 & 0.009 & 0.017 & 0.004 & 0.018 & 0.004 & 0.040 & 0.006 & 0.035 & 0.006 \\
\hline 12 & 0.099 & 0.010 & 0.021 & 0.005 & 0.227 & 0.015 & 0.368 & 0.019 & 0.266 & 0.016 \\
\hline
\end{tabular}


estimated by the Page model. A satisfactory adjustment of the model to the experimental values was.

The drying time of the product was inversely proportional to the temperature; in other words, the higher the temperature, the shorter the drying time. The drying times for $40^{\circ} \mathrm{C}$ and $100^{\circ} \mathrm{C}$ were 18.6 hours and 4.7 hours, respectively. Corrêa et al. (2010) reported that the reduction in the moisture content of agricultural products, especially of grains and seeds, occurs with decreasing order with increasing temperature due to the difference in the surface moisture and the size of the whole grain. Sousa et al. (2011) and Oliveira et al. (2012) reported similar results for the drying of forage turnip seeds and corn, respectively.

Table 5 shows the values of the coefficients "k" and " $n$ " of the Page model fitted to experimental data describing the kinetics of soybean grain drying at different temperatures.

The magnitude of the drying constant $k$ for the Page model represents the phenomenon whereby temperature increases in the drying air result in increasingly favorable external drying conditions. However, the coefficient $n$ of the Page model was not affected by drying temperature. Thus, for the range of temperatures studied, the drying of soybean grains can be estimated using the following expression:

$R X \quad \exp \quad 0.0702 \quad 0.0033 T \quad t^{1.0764}$

where:

T: drying temperature $\left({ }^{\circ} \mathrm{C}\right)$

$\mathrm{t}$ : drying time (h)

Figure 2 shows the experimental and the estimated data for the moisture content ratio (RX) obtained using the Page model, the values obtained using equation 22 and the values presented in Table 2 . This model provided a good adjustment to the data while adequately describing the process of soybean grain drying. The reduction in the moisture content ratio leads to a greater discrepancy between the estimated and experimental values.

The values of the effective diffusion coefficient of soybeans as a function of the conditions of the drying air are shown in Figure 3.

The effective diffusion coefficient increased linearly with increasing temperature of the drying air, with values of $0.847 \times 10^{-11}$ to $3.46 \times 10^{-11}$ $\mathrm{m}^{2} \mathrm{~s}^{-1}$ for temperatures ranging from 40 to $100^{\circ} \mathrm{C}$, indicating a greater intensity of water transport from the inside to the periphery of the grain and corroborating results obtained by Mohapatra and Rao (2005), Resende et al. (2008), Almeida et al. (2009), Costa et al. (2011), Corrêa et al. (2011) and Siqueira et al. (2012). Madamba et al. (1996) reported that the effective diffusion coefficients were on the order of $10^{-11}$ to $10^{-9} \mathrm{~m}^{2} \mathrm{~s}^{-1}$.

Sousa et al. (2011) studied the drying of fodder radish seeds and obtained values similar to those found in the present work on the order of $3.23 \times 10^{-11}$ to $10.42 \times 10^{-11} \mathrm{~m}^{2} \cdot \mathrm{s}^{-1}$ at temperatures of 30 and $70^{\circ} \mathrm{C}$, respectively. Gely and Santalla (2007) and Oliveira et al. (2009) encountered values on the order of $1.18 \times 10^{-12}$ to $6.76 \times 10^{-12} \mathrm{~m}^{2} . \mathrm{s}^{-1}$ and $1.54 \times 10^{-13}$ to $4.85 \times 10^{-13} \mathrm{~m}^{2} . \mathrm{s}^{-1} \mathrm{~m}^{2} . \mathrm{s}^{-1}$ for the diffusion coefficients of quinoa seeds and corn grains, respectively. Thus, water is removed more rapidly from soybeans than from quinoa seeds and corn grains.
The dependence of the effective diffusion coefficient of the soybean grains on the drying air temperature was represented by the Arrhenius expression, as illustrated in Figure 4.

The activation energy is defined as the ease with which water molecules overcome the energy barrier for migration from the interior of the

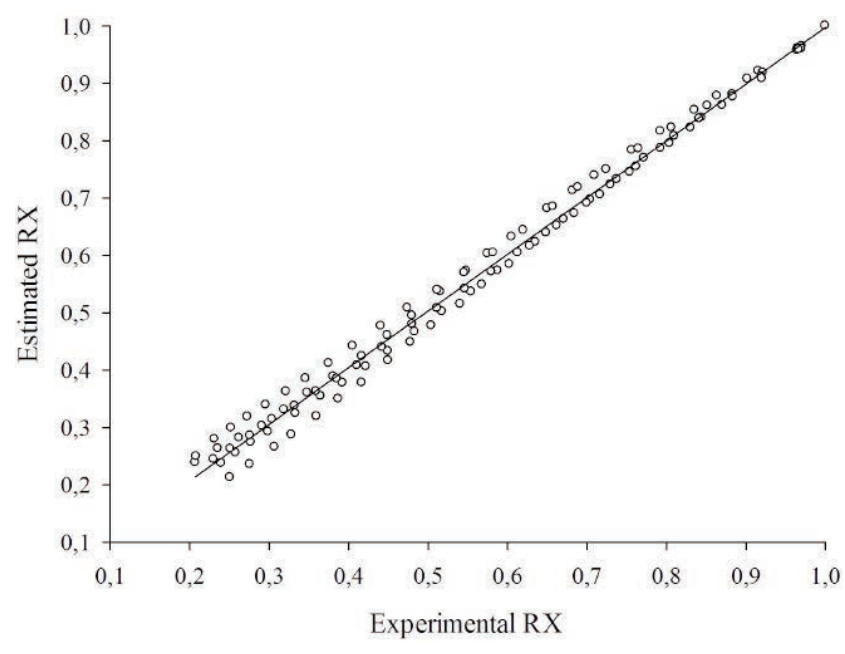

Figure 2. Experimental and estimated values of the moisture content ratio obtained using the Page model as a function of soybean drying temperature.

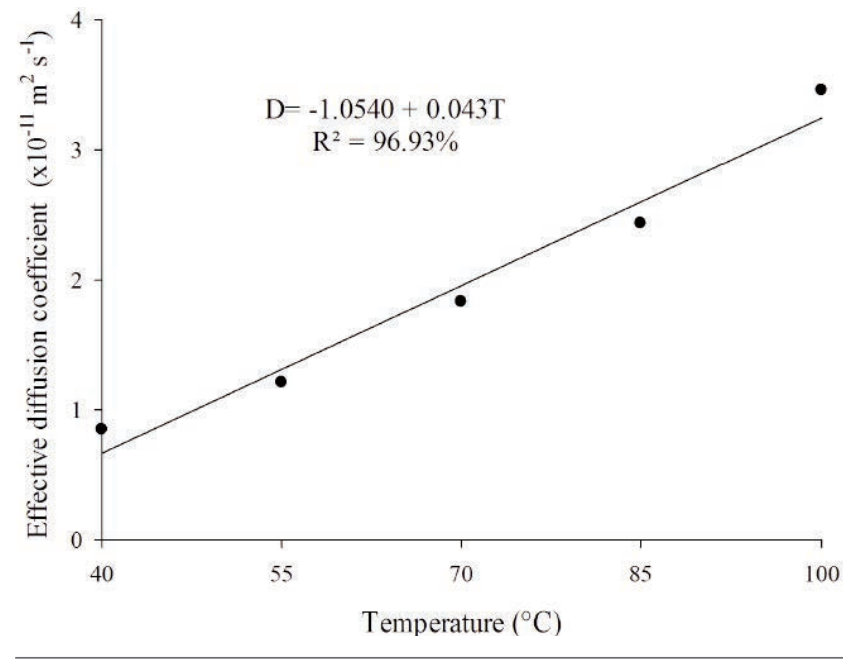

Figure 3. Average values of the effective diffusion coefficient $\left(\mathrm{m}^{2} \cdot \mathrm{s}^{-1}\right)$ obtained for soybean grains drying at temperatures of $40 ; 55 ; 70 ; 85$ and $100^{\circ} \mathrm{C}$.

Table 5. Coefficients of the Page model adjusted for different drying conditions of Valiosa cultivar soybean grains.

\begin{tabular}{|c|c|c|c|c|c|c|}
\hline \multirow[b]{2}{*}{ Coefficient } & \multicolumn{6}{|c|}{ Temperature $\left({ }^{\circ} \mathrm{C}\right)$} \\
\hline & 40 & 55 & 70 & 85 & 100 & Average values \\
\hline K & $0.0727^{*}$ & $0.1138^{*}$ & $0.1505^{*}$ & $0.1962^{*}$ & $0.2813^{*}$ & $k=-0.0702+0.0033 T$ \\
\hline $\mathrm{N}$ & $1.0327^{*}$ & $1.0178^{*}$ & $1.0981^{*}$ & $1.1311^{*}$ & $1.1022^{*}$ & 1.0764 \\
\hline
\end{tabular}

\footnotetext{
*Significant at $1 \%$ by test t.
} 
Table 6. Values of enthalpy $\left(\mathrm{H}, \mathrm{J} \mathrm{mol}^{-1}\right)$, entropy $\left(\mathrm{S}, \mathrm{J}\right.$ mol-1 $\left.\mathrm{K}^{-1}\right)$ and Gibbs free energy $\left(\mathrm{G}, \mathrm{J} \mathrm{mol}^{-1}\right)$ for different conditions of drying air used for Valiosa cultivar soybean grains.

\begin{tabular}{lcccccc} 
Thermodynamic & \multicolumn{3}{c}{ Temperature $\left({ }^{\circ} \mathrm{C}\right)$} & & Equation & $\mathrm{R}^{2}(\%)$ \\
properties & 40 & 55 & 70 & 85 & 100 & H=20496.9-8.3T \\
$\mathrm{H}$ & 20164.4 & 20039.7 & 19914.9 & 19790.2 & 19665.5 & $\mathrm{~S}=-272.9-0.16 \mathrm{~T}$ \\
$\mathrm{~S}$ & -267.1 & -263.8 & -261.8 & -259.9 & -257.3 & $\mathrm{G}=95726.6+200.3 \mathrm{~T}$ \\
\hline $\mathrm{G}$ & 103810.6 & 106596.0 & 109758.2 & 112899.5 & 115683.5 & \\
\hline
\end{tabular}

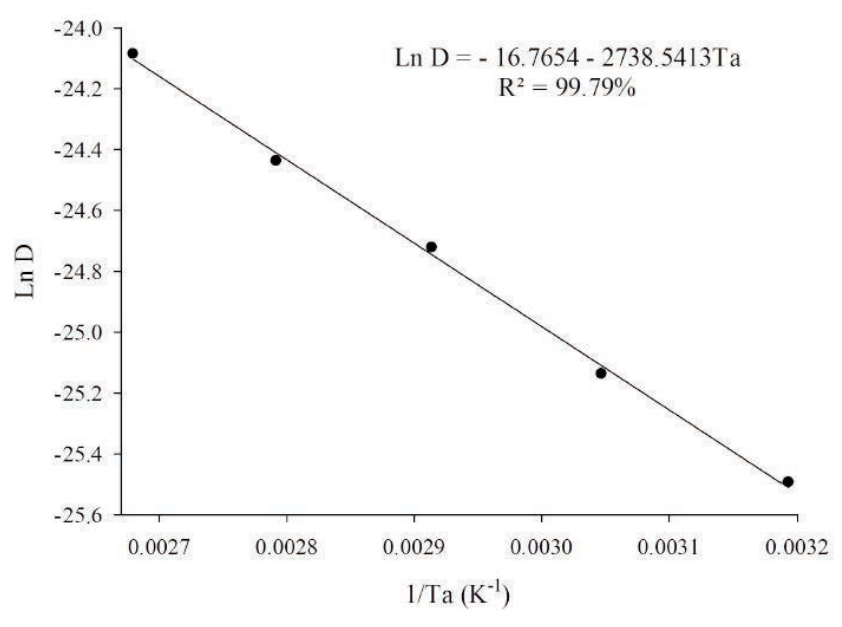

Figure 4. Arrhenius representation for the effective diffusion coefficient for soybean drying at temperatures of $40 ; 55 ; 70 ; 85$ and $100^{\circ} \mathrm{C}$.

product to its exterior (Resende et al., 2005). In the present work, the activation energy for the liquid diffusion of soybeans was $22.77 \mathrm{~kJ} . \mathrm{mol}-$ 1 in the studied temperature range. According to Zogzas et al. (1996), the activation energy for agricultural products ranges from 12.7 to 110 kJ.mol-1; thus, the value obtained in the present study is within this range.

Kitic and Viollaz (1984) obtained a value close to that found in the present work. These authors reported an activation energy for the soy-

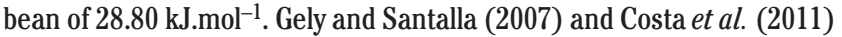
evaluated the drying of quinoa and crambe and reported activation energies of 37.97 and $37.07 \mathrm{~kJ}^{\mathrm{mol}}{ }^{-1}$, respectively. The activation energy of soybean encountered in the present study was lower than that found in other studies; this may be due to the more unstable bond between water and the product evaluated, as reported by Siqueira et al. (2012).

Table 6 shows the values of enthalpy, entropy and Gibbs free energy for the different drying conditions. The enthalpy and entropy decreased while the Gibbs free energy increased linearly with increasing drying temperature.

The enthalpy is related to the energy required to remove water from the product during the drying process; thus, the enthalpy decreases with increasing drying temperature (Oliveira et al., 2010). This behavior was observed for soybean grains during the reduction of the moisture content, indicating that lower temperatures require more energy.

According to Goneli et al. (2010), the entropy is a thermodynamic property that can be related to the degree of disorder between the water and the product. The entropy decreases with increasing drying air temperature. Corrêa et al. (2010) reported that this behavior is expected because the decrease in drying temperature decreases the excitation of water molecules of the products and increases the order of the waterproduct system.

The Gibbs free energy is related to the work required to produce available sorption sites (Nkolo Meze'e et al., 2008). The Gibbs free energy can be positive for endogenous reactions where it is necessary to add energy from the environment. The Gibbs free energy can be negative when the phenomenon occurs spontaneously without the addition of energy. The Gibbs free energy of soybean grains was found to be positive and increased with increasing drying temperature. This behavior was also observed by Corrêa etal. (2011) when studying the thermodynamic properties of corn cobs drying at temperatures of 45,55 and $65^{\circ} \mathrm{C}$.

Equations used to determine the enthalpy, the entropy and the Gibbs free energy for the temperature range studied can be found in Table 6 . These thermodynamic properties behaved in a linear manner and were characterized by high coefficients of determination.

\section{Conclusions}

All of the analyzed models satisfactorily represented the drying of grains; however, the Page model, due to its simplicity, was chosen to best represent the phenomenon.

The effective diffusion coefficient of soybeans increased with increasing drying air temperature; this phenomenon was described by the Arrhenius equation and characterized by an activation energy of $22.77 \mathrm{~kJ} \cdot \mathrm{mol}^{-1}$.

The enthalpy and entropy decreased with increasing drying temperature and the entropy was negative at all temperatures studied. The Gibbs free energy was positive for the analyzed conditions and increased with increasing drying temperature.

\section{References}

Almeida, D.P.; Resende, 0.; Costa, L.M.; Mendes, U.C.; Sales, J.F. 2009. Cinética de secagem do feijão adzuki (Vigna angularis) [Drying kinetics of adzuki beans (Vigna angularis)]. Gl. Sci Technol. 2:7283.

American Society of Agricutural Engineers (ASAE). 1988. Agricultural Engineers Handbook.

ASAE, 35th, St. Joseph.

Brasil, Ministério da Agricultura e Reforma Agrária. Secretaria Nacional de defesa Agropecuária. 2009. Regras para Análise de Sementes [Regulations for Testing Seeds]. Brasília, 395p.

Carvalho, P.T. 2012. Balanço de emissões de gases de efeito estufa de biodiesel produzido a partir de soja e dendê no Brasil [Balance of emissions of greenhouse gases from biodiesel produced from soybean oil and palm oil in Brazil]. 2012. 166f. Dissertação (Mestrado) 
apresentada ao Programa de Pós-graduação em Planejamento Energético, COPPE, da Universidade Federal do Rio de Janeiro.

Corrêa, P.C.; Araújo, E.F.; Afonso Júnior, P.C. 2003. Determinação dos parâmetros de secagem em camada delgada de sementes de milho doce (Zea mays L.) [Determination of the parameters related to thin-layer drying of sweet corn seeds (Zea mays L.)]. Rev. Bras. Milho e Sorgo. 2:110-9.

Corrêa, P.C.; Resende, 0.; Goneli, A.L.D.; Botelho, F.M.; Nogueira, B.L. 2006.

Determinação do coeficiente de difusão liquida dos grãos de feijão [Determination of the liquid diffusion coefficient of bean grains]. Rev. Bras. Prod. Agro. 8:117-126.

Corrêa, P.C.; Oliveira, G.H.H.; Botelho, F.M.; Goneli, A.L.D.; Carvalho, F.M. 2010.

Modelagem matemática e determinação das propriedades termodinâmicas do café (Coffea arábica L.) durante 0 processo de secagem [Mathematical modeling and determination of the thermodynamic properties of coffee (Coffea arabica L.) during the drying process]. Rev. Ceres. 57:595-601.

Corrêa, P.C.; Botelho, F.M.; Oliveira, G.H.H.; Goneli, A.L.D.; Resende, 0.; Campos, S.C.

2011. Mathematical modeling of the drying process of corn ears. Acta Scientiarum. Agronomy. 33:575-581.

Costa, L.M.; Resende, 0.; Sousa, K.A.; Gonçalves, D.N. 2011. Coeficiente de difusão efetivo e modelagem matemática da secagem de sementes de crambe [Effective diffusion coefficient and mathematical modeling of the drying of crambe seeds]. Rev. Bras. Eng. Agr. Amb. 15:1089-1096.

Gely, M.C.; Santalla, E.M. 2007. Moisture diffusivity in quinoa (Chenopodium quinoa

Willd.) seeds: Effect of air temperature and initial moisture content of seeds. J. Food Eng.

78:1029-1033.

Goneli, A.L.D.; Corrêa, P.C.; Afonso Júnior, P.C.; Oliveira, G.H.H. 2009. Cinética de secagem dos grãos de café descascados em camada delgada [Kinetics of thin-layer drying of peeled coffee beans]. Rev. Bras. Arm. 11:64-73.

Goneli, A.L.D.; Corrêa, P.C.; Oliveira, G.H.H.; Botelho, F.M. 2010. Water desorption and thermodynamic properties of okra seeds. Transactions of the ASAE. 53:191-197.

Günhan, T.; Demir, V.; Hancioglu, E.; Hepbasli, A. 2005. Mathematical modelling of drying of bay leaves. E. Conv. Manag. 46:1667-1679.

Jideani, V.A.; Mpotokwana, S.M. 2009. Modeling of water absorption of botswana bambara varieties using Peleg's equation. J. Food Eng. 92:182-188.

Kitic, D.; Viollaz, P.E. 1984. Comparison of drying kinetic of soybean in thin layer and fluidized beds. Int. J. Food Sc. Tech. 19:399-408.

Madamba, P.S.; Driscoll, R.H.; Buckle, K.A. 1996. Thin-layer drying characteristics of garlic slices. J. Food Eng. 29:75-97.

Mohapatra, D.; Rao, P. S. 2005. A Thin layer drying model of parboiled wheat. J. Food Eng.

66: 513-518.

Mohsenin, N.N. 1986. Physical properties of plant and animal materials. New York: Gordon and Breach Publishers.

Nkolo Meze'e, Y.N.; Noah Ngamveng, J.; Bardet, S. 2008. Effect of enthalpy-entropy compensation during sorption of water vapour in tropical woods: the case of bubinga (Guibourtia Tessmanii J. L Eonard; G. Pellegriniana J.L.). Therm. Acta. 468:1-5.

Oliveira, D.E.C.; Resende, 0.; Smaniotto, T.A.S.; Campos, R.C.; Chaves, T.H. 2012. Cinética dos grãos de milho [Kinetics of corn grains] Rev. Bras. Milho Sorgo. 11:189-201.

Oliveira, G.H.H; Corrêa P.C.; Araújo E.F.; Valente, D.S.M.; Botelho F.M. 2010. Desorption isotherms and thermodynamic properties of sweet corn cultivars (Zea mays L.). Int. J. Food Sc. Tech. 45:546-554.

Queiroz, D.M.; Corrêa, P.C.; Souza, C.M.A. 1999. Simsec - Um programa para simulação de secagem [SIMSEC - A software for drying simulation]. In: Conferência Brasileira de Pós-Colheita, 1, Porto Alegre, 1999. Anais. Passo Fundo: Abrapós; Cesa; Embrapa Trigo, p.248.

Resende, 0.; Corrêa, P.C.; Goneli, A.L. D.; Botelho, F.M.; Rodrigues, S. 2008. Modelagem matemática do processo de secagem de duas variedades de feijão (Phaseolus vulgaris L.) [Mathematical modeling of the drying process of two varieties of common bean (Phaseolus vulgaris L.) ]. Rev. Bras. Prod. Agro. 10:17-26.

Resende, 0.; Corrêa, P.C.; Goneli, A.L.D.; Martinazzo, A.P.; Ribeiro, R.M. 2005. Contração volumétrica na difusão líquida durante o processo de secagem do arroz em casca [Volumetric contraction in liquid diffusion during the drying of paddy rice]. Rev. Bras. Arm. 30:163171.

Siqueira, V. C.; Resende, 0.; Chaves, T. H. 2012. Difusividade efetiva de grãos e frutos de pinhão-manso [Effective diffusivity of grains and fruits of Jatropha curcas]. Sem. Ci. Agr. 33:2919-2930.

Souza, K.A.; Resende, 0.; Chaves, T.H.; Moreira, L.C.; 2011. Cinética de secagem do nabo forrageiro (Raphanus sativus L.) [Drying kinetics of forage turnips (Raphanus sativus L.) ]. Rev. Ci. Agro. 42:883-892.

Vernetti, F.J.; Vernetti Junior, F.J.; 2009. Genética da Soja: Caracteres Qualitativos e Diversidade Genética [Soybean Genetics: Genetic Diversity and Qualitative Characteristics]. Embrapa Informação Tecnológica, Brasília- DF, 221p.

Zogzas, N.P.; Maroulis, Z.B.; Marinos-Kouris, D. 1996. Moisture diffusivity data compilation in foodstuffs. Drying Technology. 14:22252253. 